\title{
Reflections on the Economy of ASEAN countries in the face of the Covid-19 Pandemic
}

\author{
Linh Benson ${ }^{1}$, Tienne Nhung ${ }^{1}$ \\ ${ }^{1}$ Faculty of International Business and Economics, Vietnam National University, Vietnam \\ Received: December 29, 2020 \\ Revised: January 5, 2021 \\ Accepted: January 8, 2021
}

\section{Abstract}

This article discusses the Economic Reflections of Asean countries in facing the Covid-19 Pandemic in several Asean countries, namely Vietnam, Malaysia and Indonesia. Vietnam's economic growth was victorious; the economies of various countries in other Southeast Asian regions were battered by the corona virus. The process of economic growth is influenced by two kinds of factors, namely economic factors and non-economic factors. Economic factors, which are none other than production factors, are the main force affecting economic growth. Malaysia has proven to the world community that its country is capable of managing its economy even in challenging circumstances. He quoted the IMF as global economy recorded negative growth and in Indonesia it seems that contraction in income activities in some income classes is affected. In the second quarter there is a slowdown, then in the third quarter the savings are enormous. It could be that consumption, which has been a factor in economic growth, will be a challenge in an effort to maintain economic stability during the Covid-19 pandemic. This reflects that the economies of ASEAN countries, even in the world, are currently under the same pressure due to the Covid-19 virus pandemic, the world economy this year will experience a recession.

Keywords: Economic Reflection, Covid-19, ASEAN

\section{Introduction}

The development of the Covid-19 pandemic could dramatically change the prospects for the global economy. It could be better or for the worse. This is expressed by the International Monetary Fund (IMF), in its quarterly report on the prospects for the world economy. In various parts of the world, benchmarks in an economic development are based on several indicators that must be met in order to be used as an illustration that the country is going through the process of economic development. These indicators include economic and social indicators. Economic indicators include the rate of economic growth as a process of increasing output per capita over a long period of time and an increase in Gross National Product per capita. Economic growth is the process of increasing per capita output in the long run. The emphasis is on three aspects, namely: process, per capita output and long term. Economic growth is a process, not a picture of the economy at a time. The economies of countries in the world are currently under pressure due to the corona virus pandemic (Barbier, 2020; Norouzi et al., 2020; Sokol \& Pataccini, 2020). ession since the world war. The World Bank predicts that by the end of the year, the global Gross Domestic Product (GDP) will experience contraction or negative growth of 5.2 percent this year.

Here we look at the dynamic aspects of an economy, namely how an economy develops or changes from time to time. The emphasis is on change or development itself. Economic factors together with non-economic factors influence economic progress (Hadjimichalis, 2006). Therefore, non-economic factors such as social, cultural and political factors also have an important meaning in economic growth. Many economists put forward theories about

Copyright (C) 2021, Journal of Asian Multicultural Research for Economy and Management Study, Under the license CC BY-SA 4.0 
economic growth. Economic growth is one of the investigations that has long been discussed by economists. There are many figures and their thoughts or theories regarding economic development or growth so far.

Regarding the factors that determine development, population development will encourage economic development and regarding the features of the economic growth process, development has occurred, the process will continue cumulatively. Growth in process means that economic growth is not an overview of the economy at a moment (Balaguer \& Cantavella-Jorda, 2002). Economic growth is also related to output per capita, which means that two things must be considered, namely total output and population, because per capita output is the total output divided by the number of residents (Cai et al., 2002). The aspect of not being long means that the increase in output per capita must be seen from a long period of time. An increase in per capita output in one or two years will be followed by a decline, not economic growth. During the Covid-19 pandemic, it is predicted that economic activity in developed countries will be depressed by up to 7 percent in line with the blows that occur in terms of demand, supply, trade and financial markets (Song \& Zhou, 2020). Negative growth for emerging markets for the first time in six years.

\section{The economy of the pandemic problem has an impact in Malaysia}

Malaysia's economic potential may contract. The central bank could reduce its benchmark interest rate by 50 basis points given the low inflation outlook, while the ringgit may still underperform in Asia due to the influence of oil prices. In the same period in 2019, Malaysia's economic growth reached 4.9 percent. As for the first quarter of 2020, Malaysia's economic growth reached 0.7 percent. Bank Negara Malaysia (BNM) and the Department of Statistics Malaysia, which released the economic growth data today, stated that all economic sectors were observed to experience negative growth in the second quarter of 2020. Malaysia has proven to the world community that its country is capable of managing its economy even in challenging circumstances (Katz et al., 2020; Bakar et al.,2020). He quoted the IMF global economy as having recorded negative growth in the range of 4.4 percent this year.

World trade also fell to a level of 10.4 percent (Barua, 2020). The crisis that occurred during this period also had an economic impact on more than 150 countries. This is the worst economic crisis since the Great Depression era in the 1930s," he said. He said the government had implemented social restrictions, which in Malaysia was called the Movement Control Order which had a sudden impact on the people's economic and social activities.

\section{Economic Growth in Vietnam}

The Southeast Asian country has reported more than 1,110 Covid-19 infections, with 35 deaths. However, Vietnam has reported no locally contagious infections for 47 days. Despite a lack of health infrastructure, Vietnam has been widely praised for its public health measures that have rapidly brought the Covid-19 spread to under control. Even so, the impact of the pandemic has seen economic growth slower this year and Vietnam's tourism sector has taken a hit.

Vietnam is a country with a resilient economy amid the corona virus pandemic (Nguyen \& $\mathrm{Vu}, 2020$; Linh et al., 2020; Aktar et al., 2020). While various countries have taken turns plunging into the abyss of recession, Vietnam's economy still managed to grow in the positive zone. The Vietnam Statistics Bureau reported that Vietnam's GDP growth in the third quarter of 2020 was 2.62 percent. State spending is focused on creating jobs, carrying out labor-intensive development such as repairing roads, railroads and other infrastructure. 
According to Vietnam's State Statistics Bureau, public investment since January has been at the highest level in five years. Head of the Bureau of Statistics Nguyen Thi Huong, is optimistic that positive growth will still be enjoyed in the next quarter as household consumption increases. Hanoi is trying to maintain its economic growth path through public investment and other measures as it maintains stricter virus-related restrictions than neighboring countries. While Vietnam's economic growth is thriving, the economies of other Southeast Asian countries are battered by the coronavirus. Besides Indonesia, which is predicted to be mired in a recession in the third quarter, Thailand, the Philippines and Singapore have announced an economic recession in advance.

\section{Economic turmoil and the impact on government assistance efforts in Indonesia}

Handling corona is not only done in terms of health. Handling corona from an economic point of view must also be done well. If this is not done, the economy will only get worse. This certainly has an impact on the low welfare of the community. This can further weaken people's immunity and become susceptible to disease. The government provides assistance to lower middle income earners who work in the informal sector. The assistance provided is in the form of logistics in the form of basic necessities and also assistance in the form of money provided by the government to the community, so that the welfare of the community is guaranteed. The purpose of this assistance is to prevent people's purchasing power amidst the economic downturn due to the pandemic in this country. the imposition of strict restrictions due to corona through the PSBB, causing factory closures and a drop in demand, output and new orders. This also affected factory workers by the pandemic.

COVID 19 has yet to show signs of abating in Indonesia. The hope is that in 2021, of course, we will continue to face the COVID 19 problem. The challenge, the next hope is how quickly and accurately the vaccine will be found. Interesting and important for him is the significant spike in saving in this third quarter. It seems that the contraction in income activity in several income classes was affected. In the second quarter there is a slowdown, then in the third quarter the savings are enormous. It could be that consumption, which has been a factor in economic growth, will be a challenge. In an effort to maintain economic stability during the Covid-19 pandemic, Indonesia has relied on public compliance with health protocols and economic stimulus to encourage increased household consumption and prevent a spike in unemployment.

Another theory that explains economic growth is modern economic theory. Harrod-Domar's growth theory is one of the modern economic growth theories. This theory emphasizes the importance of the formation of investment for economic growth. The higher the investment, the better the economy, investment does not only have an effect on aggregate demand but also on aggregate supply (Zhengjun, 2007).

In a developed society, economic development that is carried out will result in changes in the structure of the economy, where there is a tendency that the contribution of the agricultural sector to economic value will decrease, while the contribution of the industrial sector will increase. The industrial sector has a very important role in national and regional development, the industrial sector can provide wide employment opportunities, provide increased income to the community, generate foreign exchange generated from exports. Therefore, the economy of a region must be oriented aside from the agricultural sector, but must also be oriented towards the industrial sector (Gereffi \& Sturgeon, 2013). Benchmarks in an economic development are based on several indicators that must be met in order to be used as an illustration that the country is going through the process of economic development. These indicators include economic and social indicators. 
Economic indicators include the rate of economic growth as a process of increasing output per capita over a long period of time and an increase in Gross National Product per capita. The process of economic growth is influenced by two kinds of factors, namely economic factors and non-economic factors. Economic factors, which are none other than production factors, are the main force affecting economic growth. The decline in the rate of economic growth is a consequence of changes in the factors of production.

\section{Conclusion}

Vietnam's economic growth was victorious, the economies of various countries in other Southeast Asian regions were battered by the corona virus. Vietnam's economic growth was victorious, the economies of various countries in other Southeast Asian regions were battered by the corona virus. Malaysia has proven to the world community that its country is capable of managing its economy even in challenging circumstances. He quoted the IMF global economy as recording negative growth and in Indonesia it seems that a contraction in income activity in several income classes is affected. In the second quarter there is a slowdown, then in the third quarter the savings are enormous. It could be that consumption, which has been a factor in economic growth, will be a challenge. In an effort to maintain economic stability during the Covid-19 pandemic. Indonesia relies on public compliance with health protocols as well as economic stimuli to boost household consumption and prevent a spike in unemployment.

\section{References}

Aktar, M. A., Alam, M. M., \& Al-Amin, A. Q. (2020). Global Economic Crisis, Energy Use, CO2 Emissions, and Policy Roadmap Amid COVID-19. Sustainable Production and Consumption.

Bakar, M. A., Bakar, A. A., Noor, A. M., \& Mohamad, N. M. (2020). Islamic Technopreneurship In The Midst Of Covid-19 Pandemic: A Malaysia Review. PalArch's Journal of Archaeology of Egypt/Egyptology, 17(9), 746-765.

Balaguer, J., \& Cantavella-Jorda, M. (2002). Tourism as a long-run economic growth factor: the Spanish case. Applied economics, 34(7), 877-884.

Barbier, E. B. (2020). Greening the post-pandemic recovery in the G20. Environmental and Resource Economics, 76(4), 685-703.

Barua, S. (2020). COVID-19 pandemic and world trade: Some analytical notes. Available at SSRN 3577627.

Cai, F., Wang, D., \& Du, Y. (2002). Regional disparity and economic growth in China: The impact of labor market distortions. China Economic Review, 13(2-3), 197-212.

Gereffi, G., \& Sturgeon, T. (2013). 14 Global value chain-oriented industrial policy: the role of emerging economies. Global value chains in a changing world, 329.

Hadjimichalis, C. (2006). Non-economic factors in economic geography and in 'new regionalism': a sympathetic critique. International Journal of Urban and Regional Research, 30(3), 690-704.

Katz, R., Jung, J., \& Callorda, F. (2020). Can digitization mitigate the economic damage of a pandemic? Evidence from SARS. Telecommunications Policy, 44(10), 102044.

Linh, T. N. Q., Hanh, T. T. T., \& Shaw, R. (2020). COVID-19 initial preparedness and response in Vietnam during the first six months of the pandemic and the lessons for

Copyright (C) 2021, Journal of Asian Multicultural Research for Economy and Management Study,

Under the license CC BY-SA 4.0 
Sendai framework implementation. International Journal of Disaster Resilience in the Built Environment.

Nguyen, T. H., \& Vu, D. C. (2020). Impacts of the COVID-19 pandemic upon mental health: Perspectives from Vietnam. Psychological trauma: theory, research, practice, and policy, 12(5), 480.

Norouzi, N., de Rubens, G. Z., Choubanpishehzafar, S., \& Enevoldsen, P. (2020). When pandemics impact economies and climate change: exploring the impacts of COVID19 on oil and electricity demand in China. Energy Research \& Social Science, 68, 101654.

Sokol, M., \& Pataccini, L. (2020). Winners and losers in coronavirus times: Financialisation, financial chains and emerging economic geographies of the COVID-19 pandemic. Tijdschrift voor economische en sociale geografie, 111(3), 401-415.

Song, L., \& Zhou, Y. (2020). The COVID-19 Pandemic and Its Impact on the Global Economy: What Does It Take to Turn Crisis into Opportunity?. China \& World Economy, 28(4), 1-25.

Zhengjun, L. (2007). Harrod-Domar Model and Solow Growth Model: A Comparative Analysis. Jiangsu Social Sciences, (5), 14. 